\title{
Use of Development Dialogues in Learning and Changing Journalism Practice
}

\author{
Jaana Hujanen
}

\begin{abstract}
The present article analyses a case study in which the author experimented with use of the interventionist development dialogue method in journalism practice. Journalistic work is conceptualized as a network of multivoiced, contradictory, historically changing and artefact-mediated activity systems. Through the use of development dialogues, the study aimed at understanding and facilitating the innovation, change and expansive learning that can take place in relation to journalistic work. The data include collaboration between the researcher and four Finnish newspaper journalists, pre- and post-intervention interviews, and diaries kept by the journalists. The data were analysed using the methods of qualitative text analysis. The case study indicates that an interventionist research approach that focuses on journalists' personal experiences and needs, and makes use of concrete development tasks, is of value to them. It fosters the imagination and the creation of novel journalistic and discursive practices that help journalists reflect on, understand and pursue journalism. As power relations and control impinged on and were manifest in the research process, the development task-oriented interventionist research approach calls for a thorough evaluation that looks at the power relations within an activity system and at the question of the political aim of an interventionist research approach.
\end{abstract}

Keywords: development dialogue, intervention, expansive learning, newsroom, journalism

\section{Introduction}

As new communication forms and contextual changes in the media rewrite the traditional assumptions of news work, they make it necessary for newsrooms to reflect on and reinvent the notion of 'good' journalism and to look for alternative organizational and professional practices. Even though reform projects are a central feature of the professional news media today, in media research there is a relatively unexplored and under-theorized middle ground of organizational structures and workplace practice and learning (Cottle 2004: 4, 13). Not many academic studies have explored questions concerning, e.g., how new practices, reform projects and processes are created, managed and negotiated in newsrooms. Nor are there many interventionist studies available in the literature. Instead, studies often keep the researcher detached from the development of working practice.

The interventionist and developmental journalism studies conducted have been based on distinct theoretical roots and professional aims and practices: either on public journalism theory or developmental work research. Regarding efforts made in public 
(civic) journalism, researchers' visions of the task of journalists and of 'good' journalism have contributed to the experiments carried out within newsrooms. The public journalism approach questions objectivity and detachment as the guiding principles of journalism (Merritt 1995; Rosen 1991). Rosen states (1991: 267-274; 1994: 365-378) that the purpose of journalists is to build civic capacity and assist citizens in engaging with public life, a conceptualization that has served as a starting point for public journalism research and development projects both inside and outside the US (e.g., Heikkilä 2000; Ahva 2010).

Developmental journalism research and studies experimenting with Change Laboratory, which is a process based on cultural-historical activity theory, are more open to the local interpretations of news workers. These methodologies have been used rather as tools for journalists themselves to debate and develop their work with the help of researchers and conceptual tools designed for developing the work and enhancing learning. Instead of directing the change, the role of a researcher has been to introduce the method and its concepts and then assist in the rather complex and time-consuming intervention or learning process (e.g., Helle 2002; 2010).

In light of the existing research, there is a need for innovation practices in which every individual's theoretical and practical knowledge, understanding and expertise are recognized and innovation practices that encourage practitioners to engage in creative and democratic innovation. Previous research has shown that learning and innovationi.e. the creation and use of novel products, processes, services, technologies and ideas - are not easy for organizations to deal with. They may suffer from non-democratic practices in which practitioners are not genuinely heard but are introduced to changes in the form of ready-made solutions (Engeström 2000: 967-968; Daniels and Warmington 2007: 388).

The present article aims to contribute to application of the developmental and interventionist research approach within the context of journalistic work. It analyses how the author's case study experimented with use of the interventionist development dialogue method in Finnish journalism practice. The study attempted to understand and facilitate the innovation and expansive learning that can take place in relation to journalistic work in newspapers, i.e. the imagination and creation of novel journalistic and discursive practices to reflect on, understand and pursue journalism. I shall examine the phases and outcomes of the interventions here by analysing their strengths as well as weaknesses as modes of experimenting with new journalistic practices and enhancing expansive learning. The concerns I shall critically asses connect the systemic nature of news work, collaboration and power relations within the news organization.

Next, I shall explore cultural-historical activity theory and the development dialogue method from the viewpoint of learning and development.

\section{Journalism, Cultural-historical Activity Theory and the Developmental Dialogue}

The interventionist approach applied in the present study shares concepts and tools with the development dialogue and, more broadly, with cultural-historical activity theory. Cultural-historical activity theory is an interventionist theory of learning, innovation and change in conditions of complexity. It conceptualizes work in terms of situated 
learning and organizational sense-making (Weick 1995). A collective, artefact-mediated and object-oriented activity system is seen as the prime unit of analysis; goal-directed individual and group actions are a relatively independent but subordinate unit of analysis and understandable only when interpreted in relation to entire activity systems (Engeström 2000: 960; 2001).

The development dialogue (Mott 1992; see Helle 2002) relies on cultural-historical activity theory and developmental work research and regards work as a network of multivoiced, contradictory, historically changing and artefact-mediated activity systems. The object of activity is evolving, heterogeneous and internally contradictory (Engeström 2000). Development dialogue (Mott 1992) is a method for developing work by the practitioners themselves. It aims to combine the systemic and individual aspects of work, but makes the individual the core of the intervention and development. The emphasis is on the person's career, power to define personal needs and possibilities for development and learning, and the actions and relations between the different groups within a (work) community. In expansive learning, the outcomes are expanded objects and new collective work practices, including those of thinking and discourse. The theory perceives learning as a longitudinal process in which the participants in an activity system take specific learning actions to analyse the inner contradictions of their activity, and then design and implement a new model for their activity that expands its object (Engeström and Kerosuo 2007: 336, 339).

The development dialogue, cultural historical activity theory and developmental work research offer fruitful points of departure because they emphasize the importance of generating dialogue and the kinds of institutional practices that give practitioners an active role by inviting them to bring their voices into the discussion on the practices and objects of their work (Kurki 2002: 50-51; Kemmis and Wilkinson 1998; Bereiter 2002). The principles of the cultural-historical activity theory of the multivoicedness of activity systems and their historicity are of interest here (Engeström 2001: 136137). The concepts relate to the notion of object (Leont'ev 1978). According to this theory, there is no activity without an object that embodies the meaning, the motive and the purpose of a collective activity system. The object is given as raw material to the subjects involved in an activity, but it is interpreted, constructed and changed by the subject's actions.

This conceptualization helps in understanding the multivoicedness of a journalistic activity system, its nature as a community of multiple points of view, traditions and interests, and its historicity: a news organization takes shape and is transformed over long periods of time. Multivoicedness is a source of both trouble and innovation, demanding actions of negotiation. Contradictions, manifest in disturbances and mundane innovations, are also seen as sources of change and development (Engeström 2001: 137). Following this, the work of journalists is independent to a degree, but journalistic work needs to be studied in the wider context of newsroom and media organizations (cf. Shoemaker and Reese 1996; Fairclough 1992). Despite shared journalistic ideals and practices, the notion of 'good' journalism as the proclaimed object of the work is multi-faceted, open to innumerable interpretations. Multivoicedness and historicity can thus be seen as various discourses, organizational structures and positions that define and compete over the object of work (Reese 1990; Deuze 2005: 446). 


\section{The Context, Data and Method}

My research project included qualitative interview data and interventionist collaboration (development tasks) with journalists and news management in three Finnish newspaper newsrooms. Newspapers continue to constitute an important sector of the Finnish media, financially and in terms of prestige and political and social impact. The newspapers involved were Keskipohjanmaa (one journalist), Keskisuomalainen (two journalists, an executive news editor and a producer) and Savon Sanomat (one journalist). They are the only daily newspapers in their respective areas and have fairly stable circulations of between 27,000 and 75,000. All the papers have carried out reform projects, for example to promote reader-friendliness.

Because the system view of an organization was seen as insufficient when trying to understand and facilitate qualitative changes by means of expansive learning, besides gathering interview data I looked for "flesh-and-blood" dialogue participants with their own emotions, values, hopes and needs (Engeström and Kerosuo 2007: 304). As regards gathering the data, I first contacted news editors who then provided me with a list of prospective interviewees. The first interviews (26), my pre-intervention data, focused on how the tasks of journalists were represented and what kind of readers were constructed, as well as how journalists made sense of news policy, journalistic practices and innovation processes (see Hujanen 2008 and 2009 for a discourse analysis of this data). The role and emphasis of this phase was thus to learn about on-going and recent change projects within the newsrooms and about interviewees' perceptions of the idea(l)s and practices of journalism. I interviewed journalists at various levels in the newsroom hierarchy to obtain a rich spectrum of conceptualizations. The management illuminated the objectives of reform projects while journalists shed light on how the ideals were negotiated on the level of everyday work.

The interventionist part of the study started in the spring of 2003, for which four volunteer dialogue participants, i.e. journalists, were selected out of the 26 interviewees. An essential criterion for selecting the dialogue participants was that they were interested in elaborating and sharing their work with me, i.e. the academic researcher, and imagining and learning new ways of pursuing journalism. Another prerequisite was the positive attitude of newsroom management towards the use of development tasks. The journalist participants were experienced female journalists: a business journalist and a news journalist from Keskisuomalainen. The journalists from Keskipohjanmaa and Savon Sanomat worked outside the main newsroom in small local newsrooms as local journalists in submanagerial positions. Their everyday work was fairly free, although they did discuss their stories with the main newsroom. By choosing these journalists, different kinds of journalist roles and conditions for work, change and learning were included in the data setting.

I worked in collaboration with these participating journalists for a year in order to explore learning and change as a process through the perceptions, experiences and understandings of the participants themselves. The intervention was steered towards creating and experimenting with citizen-based and reader-oriented journalism. The journalists undertook development tasks reflecting this aim. Various types of communication took place between myself and the journalists and their line managers. The participating journalists kept diaries about their tasks and learning. Face-to-face interviews with them were conducted soon after the intervention (2004) and e-mail interviews two years thereafter (2006). 
The post-intervention interviews focused on how the participating journalists felt about the research approach as a learning and change process, on the practices with which they had experimented, and on the outcomes. All of the interviews, which lasted between one and two hours, were recorded and transcribed. In their diaries, the journalists reflected on their learning actions, our meetings, my comments and the role of their colleagues and newsroom. The interview and diary data were analysed using the methods of qualitative text analysis (Hujanen 2008). This article addresses all the data gathered.

I shall next analyse how development dialogue was applied as a method of journalistic experimentation.

\section{Development Dialogue to Enhance Learning and Innovation in Journalism}

In the pre-intervention interview data, conflicts and multivoicedness characterized the debates on change efforts and reader-oriented news. Reader-driven as a news ideal was not a shared ideal. Journalists and news management disagreed on it by drawing on conflicting journalistic discourses: news management drew mainly on market-oriented journalism and journalists on societal journalism (Hujanen 2009). In the discourse of market-oriented journalism, editorial autonomy and journalists' right to create innovations were invoked in the face of audiences: journalists do not need a conceptualization of the tasks of journalism. Instead, it is important to listen to reader feedback and sales figures.

As it emerged in the interviews, contradictions and troubles also related to the lack of democracy in the ways reform projects had been launched in the newspapers. Editorsin-chief and executive news editors played an important role not only in leading the change processes, but also in suggesting best practices for the future. Their views, according to the journalists interviewed, were presented as the organization's line - "thatis-how-we-will-do-it-here" (see de Bruin 2000: 232-233) - while the journalists felt they lacked genuine opportunities to speak and be heard. The journalists made claims of non-democratic practices by portraying them as restrictive and rigidly imposed. This contributed to the journalists' resistance to constructing a new professional identity and process of change.

To me it's pretty short-sighted if the executives and management people think that only they know what's good and where we should be heading. It's interesting that we, the content producers, try to listen more to the ordinary people but within the organization it doesn't happen... that's where it's at in my mind, it would provide a clear direction.

The data support Engeström's (2000: 967) observation that management's fixed learning assignment to practitioners is typically rejected and a new direction emerges. This can be problematic from the viewpoint of expansive learning and creating novel practices. The innovation process in the case of journalism is about re-conceptualizing the news ideal and about opening up the old routine, which, in light of the data gathered, cannot be achieved as a managerial decision only. As the news orientation towards social and political elites had been replaced in the policy by an orientation towards the everyday, journalism practice still needed to be reinvented on the levels of information gathering, writing and editing. Echoing this, the journalists expressed the need to explain the policy: 
Such slogans as 'public or citizen journalism', 'human interest', 'going out on the streets' circulate here. In my opinion, this is the problem, they are just slogans but they have not been explained on the level of news stories.

The prior intervention interviews confirmed that there is a need for an interventionist approach in which journalists themselves are the key actors and are given space for creative action. Instead of offering direct suggestions or solutions, I as a researcher and collaborating partner aimed at acting as a resource person with whom journalists could discuss both the object and meaning of their work and their stories, i.e. the development tasks. The purpose was not to transfer readymade ideas and practices into the workplace from outside, but to foster practitioners' own search for new ways of working and to encourage them to learn by doing. Nor was the aim that I as the researcher should replace the newsroom manager or editor in charge of the everyday news work. My role as a collaborative resource was to provide additional opportunities, questions and angles that would help the journalists to reflect on the inner contradictions of their activity, and to find new ideas for personal and organisational development.

\section{Creation of the Development Tasks}

The creation of development tasks followed the interviews. The development tasks were meant to be useful not only from the viewpoint of the participating journalists' individual learning and personal needs, but also for the needs of their newsrooms. According to Mott (1992; Helle 2002), a good development task covers both the aims of the organization and the professional competence and practices of an individual practitioner. It needs to be personal in the sense that the individual is willing to carry it out. It should not be overwhelming or too general a task, nor should it be too easy or self-evident. Rather, a good development task should be concrete and viable and offered with resources, such as time, equipment, training and support from the work community.

In the present study, the participating journalists were given the freedom and responsibility to create and carry out the development tasks themselves, with the assistance of the researcher, myself, and the news management. Ways of pursuing reader-oriented journalism from a societal perspective were chosen as the focus because the journalists were concerned over the growing focus on market-driven journalism. Kemmis (2006: 460-469) calls for action research that looks at the effectiveness of practices in terms of their social, cultural, discursive and material-economic historical consequences. By putting the focus of tasks involving creating citizen-based knowledge on societally relevant topics, the present study was not only about improving techniques of journalistic work, but also about seeing them as being connected to the role of journalism in society.

While journalists worked on the tasks the communication between them, the newsrooms and myself assumed distinct roles and made use of various technologies, including telephone, e-mail, face-to-face meetings, and oral and written feedback. For example, I participated in the ideation sessions of the learning actions. In the case of Keskisuomalainen, the news management was integrated into the project: the producer and the head of business news participated in the discussions and supervised the journalist in her development tasks. This gave the development tasks a good start; it highlighted the systemic aspect of innovation and worked as a sign of management's interest in journalists' efforts. 
In the small group meetings throughout the project, the topics of the stories and the ways of producing citizen-based knowledge were developed further. The aim of this phase was to develop new practices for producing citizen-based knowledge and to learn by discussing journalistic work. To nurture discussion and learning, I shared my own theoretical and practical knowledge by commenting on the debates within journalism research on participatory and citizen journalism. I also wrote a resource briefing paper that drew on the extensive interview data collected at the beginning of the project. The paper summarized journalists' own ideas and experiences of pursuing citizen-based knowledge and practices that could enhance dialogue about 'good' journalism within the newsroom. In light of the diary and post-intervention data, the meetings and the resource briefing paper served as a good basis for reflection, assignments and discussion (cf. Hill et al. 2007: 365).

I shall next consider the outcomes of the intervention by paying attention to its strengths as well as weaknesses as a mode of experimenting with new journalistic practices and enhancing expansive learning.

\section{Strengths: You Learn by Doing}

In the interview and diary data analysed, the journalists described the intervention and working on the developments tasks as "interesting", "challenging" and "rewarding" and "a nice break from the journalistic grind", but also as "difficult" and "frustrating". Those involved learned novel practices and found new objects for innovation through experimentation. The best reward for all their hard work seemed to be positive feedback and contacts from colleagues, readers or other people involved in the development task. The journalists were happy when they saw they had succeeded in discussing a topical societal question and bringing new voices into the public space.

The intervention strengthened some journalists' will and abilities to seek new personal meaning in their work. In the aftermath of the project, one journalist looked for ways to pursue more profound journalism and began writing a book she thought would give her better satisfaction outside work. Another journalist whose assignments dealt with local social and health care issues resigned from the newspaper she worked for during the project. After her first stories were printed in the paper, she received an invitation to become part of the development of local social and health care services. In a postintervention interview, she reported that she was running her own business where she could better fulfil her personal needs. She believed that working on development tasks and our discussions on her work had played a role in her decision. She said it made her see that her boss did not show interest in the stories on which she had spent a great deal of time and energy. Her decision to resign might thus illustrate a situation in which a person realizes that on-the-job learning is no longer an integral part of her own authentic life project, but a preparation for compliance to the will and purposes of others (Kemmis 2006: 464).

My case study encouraged journalists to create unique and personal tasks, i.e. to experiment with information gathering practices they had thus far not used and to pursue stories on topics and angles particularly meaningful to themselves - topics they had not covered in the course of their everyday work. This worked well as a starting point: all the participating journalists and the news management representatives involved in the 
study were enthusiastic about the stories. A business editor, for example, felt that the employee perspective was missing, as business news coverage in her paper was dominated by the interests and discourse of the companies. In her development task, she produced citizen-based knowledge on how people had experienced and coped after being made redundant by a big local company. She used an information gathering practice she had not used before, i.e. she asked people who had lost their jobs to share their stories and experiences by sending letters to the newsroom.

Concrete experimentation embedded in the development tasks was perceived as encouraging and vital for learning. A task in the form of information gathering and story writing was an effective way to learn to learn, as the journalists put it. The individual effort of the journalists themselves was thus deemed very important:

You learn by doing. You realize it in a more concrete way when you first talk about it [reader-oriented journalism] and then you have to do it.

According to the journalists involved, even good reform projects may easily fizzle out because of lack of leadership and concrete experimenting. The journalists perceived that my central role in the intervention was to keep the process moving and to provide additional tools for learning and experimenting. I sent the journalists e-mails once in a while or phoned them to ask how the development task was proceeding, and whether it would be good for us to meet. The participating journalists perceived the joint sessions in which the story ideas were further discussed to be of special value; especially those journalists working in local newsrooms saw them as important because this made them feel they were not alone with their stories. The data also indicate that, in this case, collaboration with an academic researcher was valued because it offered (compared to news management) different situations for reflection on one's own work.

The construction of epistemic objects is an integral part of expert work. These objects do not have fixed qualities but rather open-ended projections oriented to something that does not yet exist. Accordingly, new collective work practices should not be seen as the only result of the interventionist research approach. There is also something that is hidden and difficult to measure: individuals' deeper understanding of the object of their work and its discursive character. In light of the data analysed, this interventionist research approach helped to crack open some of the previously hidden self-evidence and givenness of ways of acting and perceiving the object of journalistic work by making the routines into an object of enquiry. In line with Miettinen and Virkkunen (2005: 452), I argue that 'better' practices should be sought through the development of tools and organizational practices that foster dialogue and reflection as a central part of an activity.

My underlying assumption was to leave journalistic autonomy to the newsroom and not to replace the work and role of the newsroom management. However, my role included providing journalists with feedback and ideas. Before the stories were run in the papers, the journalists sent their manuscripts to me by e-mail for comments. After carefully reading the text from the viewpoint of the aims that had been set, I wrote or phoned the journalist explaining my reading of it, focusing on the genre, structure and angle of the text, the use and representation of news sources, and linguistic choices. The journalists appreciated the feedback and the fact that I made suggestions for textual revisions before publication: 
It was a luxury to have somebody else thoughtfully reading the stories through and who could be bothered to spend her time in this way.

My critical reading was mainly expressed in the form of questions: "Why did you choose to use this word here?" or "If you want to encourage readers to voice their opinions, could you think of having another voice or source at the beginning of the text?" The journalists appreciated this:

I liked the way you suggested through questions instead of directly giving advice.

Journalists did not always have time to make revisions even if they wanted to. When they had time they thought through and changed their textual and discursive choices. A business editor working on a story on people's experiences of losing their jobs stated in the interview that she was surprised at how the angle and parlance of business management, (e.g. "company efficiency drive") had insidiously entered her story. This may indicate that my feedback was different from that of the news management.

It was a surprise for me that I did not realize my linguistic choices and angle. I think it was good feedback and woke me up and I made the changes. Maybe I could have worked on the story still more and made something of it, but then the deadline was set when they decided to run the story the following day.

The case study thus illustrates how the power of development tasks lies in the fact that they demand and support learning by experimentation. The analysis indicates that a novel news policy needs to be created on the level of everyday work. In this study, the development tasks also fostered debate about journalism inside the newsrooms. This is important because without discussing conflicting perceptions of what constitutes 'good' journalism, the suggested novel practices may remain too vague and authoritative for a journalist, as Glasser and Craft (1997: 32- 33) argue. Thus, tasks and discussions related to the ideals can help practitioners develop their work and make sense of and balance their role in an increasingly hybrid news culture (see Kärreman and Alvesson 2001: 86).

\section{Critical Questions: Collaboration and Power}

Besides positive experiences, the study brought up concerns regarding the applicability of the development dialogue method in helping news workers learn to reflect on and develop their work. The disturbances and contradictions led to some differences between what had been planned and what took place. The concerns I concentrate on here are the systemic nature of news work and power relations within the news organization.

Before the news story reaches the reader, it has to pass through a complex, intertwined system of people, material artefacts, actions and negotiations. In this process, the role of news management is crucial. I had permission from management to carry out interviews and development tasks. An executive business news editor from Keskisuomalainen participated actively throughout the study. The role of the producer of the same paper diminished during the course of the project. In the rest of the papers, as anticipated, management did not play a central role in the project, because they were located in different towns than the participating journalists.

The cases in the present study suggest that troubles in journalistic work are caused by a lack of co-ordination and communication between the different actors within the 
newsroom. The troubles took the form of unclear loci of responsibility and failure to inform others in the organization about the aims, actions and plans for development (see Engeström 2000: 960, 966). The journalists involved expressed disappointment at the ways their stories were visualized and presented in the paper. This means that it is not enough to engage executive news management in participation, but also of importance are other groups within the organization: photographers, graphic and layout designers.

One of the questions the study thus raises is how to combine the individual and systemic level into one development task. Journalism is an example of work that requires negotiated networking across boundaries. Accordingly, to succeed, expansive learning and developmental dialogues require horizontal breadth both in terms of the tasks set and collective expertise. I argue that this could be achieved by means of debating and hybridizing ideas, perspectives and conceptualizations to a greater degree between different actors and positions within the news organization.

As stated, the data are characterized by multivoicedness: the notions of 'good' journalism were contested. When conceptualizations of the object of work not only differ from but also compete with each other, the fundamental question is: can a development task be meaningful for both the individual and the organization? The existence of almost opposite discourses on 'good', reader-oriented news turned out to be a source of inner conflict for the participating journalists. The market-driven news policy left journalists with space for independence and action; for example they were free to choose societally oriented topics. However, the journalists were not comfortable with their tasks towards the end of the project, because they began evaluating them in relation to the news policy of management. Some felt guilty for not developing their work according to the increasingly market-driven policy. Three journalists working on income disparities and dismissal of employees perceived their topic was contrary to the new policy, which was influenced by the RISC Monitor marketing research tool. These journalists argued that their topic was not in line with the RISC Monitor method because their story focused on a difficult social problem.

The RISC (Research Institute on Social Change) market research method studies the social atmosphere, socio-cultural maps and attitude groupings, and predicts changes in them. Finnish newspapers using the RISC as a tool for pursuing news have focused on the Individual Exploration and Economic Priority segments of the RISC quadrant (see Hujanen 2008). In the RISC model, the first segment is represented as change-oriented. People in this segment are believed to be attracted to leisure, fashion, travel, hobbies, food and horoscopes stories as well as to culture and entertainment. People in the Economic Priority segment - as individuals settled in their habits - are believed to strive for economic success, and their interests lie in cars, sports and exercise, crime, films, music, and information technology. This is how one participant journalist replied when asked if she had the RISC Monitor in mind when she pursued a story on the growing income inequality in Finland:

Indeed I had. It was horribly clear that it [RISC Monitor] disturbed me (...) One started to feel ashamed, this old story and stuff, even though I had first seen it [the story] as a big and brilliant idea. So I started to see it through the eyes of the RISC Monitor and through all those demands that the story should be topical, clearly angled, touching. And here I have this kind of a social problem and injustice. 
Conflicts in news values led to some troubles with the resources and the support the journalists received from their work community. One journalist worked on her assignment at home at weekends because at work she was busy with other duties. She felt that the producer did not have time to discuss her story towards the end of the project:

Of course it would have been ideal if the producer had had more time to talk about the story and plan it further, but then I just wasn't persistent enough because they are all such rush jobs. Perhaps it [the story on growing income inequality] just lacked punch.

Another journalist, working in a local newsroom on a story on elderly people's experiences of everyday life and care received positive feedback from the readers about the story after it had been run. This made her feel her development task had succeeded, even though she experienced the lack of recognition and feedback from her own newsroom as a disappointment:

I wish someone [within the newsroom] had understood the value of my story.

Actually, my employer didn’t really give two sh*ts for what I was doing.

As a whole, the cases illustrate how the workings of power relations in an organization are present and affect the course of learning and experimenting. How a development task is supported by the work community is an essential question. Sufficient resources for the tasks are crucial to the process of learning and finding motivation for one's work. In the present study, limited support stole some of the journalists' trust in the value of their developing tasks, but it did not make the process worthless if a positive response and recognition came from another source.

In the course of this project, it became clear that it was important that I worked with the journalists at the grassroots level, discussing and commenting on their stories. It was a surprise to me that there was such a lack of and need for detailed feedback among the journalists. So, even though I did not aim to replace the work of the news management, the study partially took me into a position similar to that of the news editor. As a researcher and teacher of journalism, I had experience of analysing journalistic texts, which helped me in my role as a commentator and tutor. In light of the data analysed, my role as a collaborative partner supported the participating journalists in several ways. For them, our discussions and feedback served as resources for innovation, reflection and learning. As an outsider with some knowledge and competence in the journalistic profession, compared to the news management, it might have been easier for me to identify the specific house style and challenge the journalists to look for alternative ways of doing their work. Because the discussions we had were intimate and confidential, it may be that they had also a therapeutic meaning for the journalists, allowing them to reflect on their personal frustrations and prospects. I argue that these experiences point towards the potential and value of researchers and media professionals engaging in joint dialogue and working together to develop alternative ways of learning about and pursuing journalism.

\section{Conclusion}

Through the use of development tasks, I assessed the imagination and creation of novel journalistic and discursive practices in relation to reflecting on, understanding and 
pursuing journalism in three Finnish daily newspapers. The case study contributes to application of the interventionist research approach within the context of journalistic work from the three entwining perspectives: i) the use and applicability of concrete, individual development tasks, ii) collaboration and the systemic nature of news work and iii) power relations within the news organization.

First, the study produced evidence that an interventionist research approach that focuses on practitioners' personal motives, experiences and needs, and that makes use of concrete and individual development tasks, is of value to them. This approach seems to recognize the importance of the theoretical and practical knowledge, understanding, and expertise professionals themselves have. In the case of the present study, the use of concrete and individual development tasks supported journalists' individual processes to 'learn to learn', experiment and reflect. Reflection itself can be seen as a crucial value in the journalism profession, where news routines and house styles are often tacitly learned. The development task method in such a context is a meaningful way of learning, as it helps to open up a routine and make it an object of reflection, and thus more receptive to transformations.

Second, the data indicate that it is important that news professionals be guided into collaborative innovation. The emergence of discontinuities, contradictions and troubles is central not only to activity systems but to developmental work methods (Engeströn and Kerosuo 2007: 337-338). The emergence of problems in the present study should thus not be seen as a failure of the project. Nevertheless something could be learned for the future interventionist approaches to journalistic work. Because different participants bring their own interests, perspectives and practices to bear on a single piece of news, the development dialogue method could be strengthened through tools that take better account of the networked nature of news work. I argue that this could be achieved by introducing team-based development tasks - teams consisting of one to two journalists, a news editor, a photographer, a visual designer and the researcher.

Third, as the study shows, pursuing development tasks - and the whole interventionist research approach - is enabled and limited by the workings of power relations within the news organization and between the news organization and the researcher. The study demonstrated that the interface and interaction of various actors in different positions - here journalists, executive news editors, and researchers - were not always smooth and easy. The stories the journalists worked on were both part of this research and part of their everyday work, which they pursued under the supervision of their line managers. When the development task did not echo the interest of the news management, the researcher as well became part of the power struggles within the organization.

The present case study thus calls for a serious evaluation of the development taskoriented intervention method from the viewpoint of power relations: how does the way in which subjects are positioned with respect to one another within an activity system have implications for engagement with and control over the tools and objects of development and learning (also Daniel and Warmington 2007: 377, 388). The study indicates that some actors, voices or ideals are prominent in the newsroom, while others struggle for recognition (Hall 1997). Here, the voices of news management, speaking for market-driven news, in the newsrooms studied were in such a powerful position that less powerful voices, including journalists working on stories on societal problems, struggled for recognition and sincere support for their aims and development tasks (see also Hujanen 2008). 
Furthermore, the workings of power relations and powerful discourses connect with the question about the political aim of interventionist research within the context journalism: can the aim of development dialogue include - besides helping individual journalists and teams learn to make a difference in how journalistic activity systems negotiate, operate and perform their objects - making a difference in what these systems operate for? In the case of journalism, a central question is whether and how the interventionist research approach within news organizations can be used as a tool for organizational reflection on both individual performance and for exploring the work of journalists and media in societies. First, this is a critical concern if we agree that the profit motive of the news organization may have a corrosive effect: journalists are not assumed to focus on societal problems when developing their work to meet the needs of future audiences. Second, exploring in more detail the role of journalism in today's society as a part of interventionist research is a key challenge, if we agree that the legitimacy of the journalism profession lies in the ideal of serving the good of society.

\section{Note}

1. To better understand contradictions in the future, the interventionist research approach to journalism practice, the development dialogue method, could be strengthened through ethnographic observation within the newsrooms, including how news management intervenes in a journalist's development task.

\section{References}

Ahva, L. (2010) Making news with citizens: Public journalism and professional reflexivity in Finnish newspapers. Tampere: Tampere University Press.

Bereiter, C. (2002) 'Design Research for Sustained Innovation', Cognitive Studies, Bulletin of the Japanese Cognitive Society 9(3): 321-327.

Cottle, S. (2004) 'Media Organisation and Production: Mapping the Field', in Cottle, S. (ed.) Media Organisation and Production, London: Sage, pp. 3-24.

Daniels, H. and Warmington, P. (2007) 'Analysing Third Generation Activity Systems: Labour-power, Subject Position and Personal Transformation’ Journal of Workplace Learning 19(6): 377-391.

de Bruin, M. (2000) 'Gender, organization and professional identities in journalism', Journalism, Theory, Practice \& Criticism 1(2): 217-238.

Deuze, M. (2005) 'What is Journalism? Professional Identity and Ideology of Journalists Reconsidered', Journalism. Theory, Practice \& Criticism 6(4): 442-464.

Engeström, Y. (2000) 'Activity Theory as a Framework for Analyzing and Redesigning Work, Ergonomics 43(7): 960-974.

Engeström, Y. (2001) 'Expansive Learning at Work: Toward an Activity Theoretical Reconcpetualization', Journal of Education and Work 14(1):133-156.

Engeström, Y. and Kerosuo, H. (2007) 'From Workplace Learning to Inter-organizational Learning and Back: the Contribution of Activity Theory', Journal of workplace learning 19(6): 336-342.

Fairclough, N. (1992) Discourse and Social Change. Cambridge: Polity Press.

Glasser, T.L. and Craft, S. (1997) 'Kansalaisjournalismi ja demokraattiset ideaalit' (Public Journalism and the Search for Democratic Ideals), Tiedotustutkimus 20 (4): 22-36.

Hall, S. (1997) 'The Work of Representation', in Hall S. (ed.) Representation: Cultural Representations and Signifying Practices, London: Sage, pp. 13-74.

Heikkilä, H. (2001) Ohut ja vankka journalismi. Kansalaisuus suomalaisen uutisjournalismin käytännöissä 1990-luvulla (Thin and Strong Journalism. Citizenship in Finnish News Practices in the 1990s). Tampere: Tampere University Press.

Helle, M. (2010) Toimitustyö muutoksessa: toiminnan teoria ja mediakonseptin käsite tutkimuksen ja kehittämisen kehyksenä. (Challenges of Changing Journalistic Work. Activity Theory and Media Concepts as Tools for Understanding and Developing Work Practices in Newsrooms). Tampere: Tampere University Press. http://acta.uta.fi/pdf/978-951-44-8313-4.pdf

Helle, M. (2002) 'Yksilötyöstä työyhteisön kehittämiseen - kehitysvuoropuhelu "Paikallislehdessä"' (From Individual Work to the Development of Workplace), Työ ja ihminen 16(3): 246-269. 
Hill, R., Capper P., Wilson, K., Whatman, R. and Wong, K. (2007) 'Workplace Learning in the New Zealand Apple Industry Network. A New Co-design Method for Government "Practice Making"', Journal of Workplace Learning 19(6): 359-376.

Hujanen, J. (2008) 'RISC Monitor audience rating and its implications for journalistic practice. Journalism. Theory, Practice and Criticism 9(2): 182-199.

Hujanen, J. (2009) 'Informing, Entertaining, Empowering. Finnish press journalists' (re)negotiation of their tasks', Journalism Practice 3(1):30-45.

Kemmis, S. (2006) 'Participatory Action Research and the Public Sphere', Educational Action Research 14(4): 459-476.

Kemmis, S. and Wilkinson, M. (1998) 'Participatory Action Research and the Study of Practice', in Atweth B., Kemmis, S. and Weeds, P. (eds.), Action Research in Practice. Partnership for Social Justice in Education, London: Routledge, pp. 21-36.

Kurki, L. (2002) Sosiokulttuurinen innostaminen (SocioCultural Animation). Tampere: Vastapaino.

Kärreman, D. and Alvesson, M. (2001) 'Making Newsmakers: Conversational Identity at Work', Organization Studies 22(1): 59-89.

Leont'ev, A.N. (1978) Activity, Consciousness, and Personality. Englewppd Cliffs, NJ: Prentice-Hall.

Merritt, D. Jr. (1995) Public Journalism and Public Life: Why Telling the News is not enough. Hillsdale NJ: Lawrence Erlbaum Associates.

Miettinen, R. and Virkkunen, J. (2005) 'Epistemic Objects, Artefacts and Organizational Change', Organization 12(3): 437-456.

Mott, L. (1992) Systemudvikling. Kobenhavn: Samfundslitteratur.

Reese, S. (1990) 'The News Paradigm and the Ideology of Objectivity: A Socialist at the Wall Street Journal', Critical Studies in Mass Communication 7(4): 390-409.

Rosen, J. (1991) 'Making Journalism More Public', Communication 12(4): 267-284.

Rosen, J. (1994) 'Making Things More Public: On the Political Responsibility of the Media Intellectual' Critical studies in mass communication 11: 363-388.

Shoemaker, P.J. and Reese, S.D. (1996) Mediating the Message. Theories of Influences on Mass Media Content. New York: Longman Publishers USA.

Stevenson, N. (1995) Understanding Media Cultures: Social Theory and Mass Communication, London: Sage. Weick, K.L. (1995) Sense-making in Organizations. Thousand Oaks: Sage. 